\title{
Special issue on youth and graduate migration
}

\author{
Alessandra Faggian' ${ }^{1}$ - Jonathan Corcoran ${ }^{2}$. \\ Francisco Rowe $\mathbf{e}^{3}$
}

Published online: 19 October 2017

(C) Springer-Verlag GmbH Germany 2017

\section{Introduction}

Young people are associated with high levels of spatial mobility which is linked to a series of life course events, involving leaving the parental home, skills development, partnership and family formation, and entry to the labour force (Rogers et al. 1978). These life course events, and their associated spatial mobility, have important consequences for both individual employment outcomes and the economic vitality of local labour markets (Faggian and McCann 2009; Venhorst et al. 2010; Corcoran and Faggian 2017). Existing scholarship has highlighted that this spatial mobility is not uniform across the urban hierarchy. Rural areas are subject to persistent pressures to attract and retain youth and in particular young educated people to help redress accelerating ageing populations and replenishing labour gaps as well as to act as a key ingredient in stimulating economic development (Corcoran et al. 2010; Stockdale 2006). In contrast, larger metropolitan areas are magnets attracting the 'best' and the 'brightest' (Costa and Kahn 2000; Ritsilä and Ovaskainen 2001). At the expense of smaller towns and rural areas, young people migrate up the urban hierarchy in search

$\triangle$ Alessandra Faggian

alessandra.faggian@gssi.it

Jonathan Corcoran

jj.corcoran@uq.edu.au

Francisco Rowe

F.Rowe-Gonzalez@liverpool.ac.uk

1 Gran Sasso Science Institute, Social Sciences, L'Aquila, Italy

2 School of Earth and Environmental Sciences, The University of Queensland, Brisbane, Australia

3 Geography and Planning, University of Liverpool, Liverpool, UK 
of enhanced education, employment and lifestyle opportunities (Artz 2003; Gibson and McKenzie 2012).

Not surprisingly, given the significance of the topic, youth and graduate migration has attracted continued attention across the media, policy debates and academic circles concerning both the challenges and opportunities that it presents to individuals, labour markets and national economies (United Nations 2016; Global Migration Group 2014). From a regional labour market perspective, there is continued interest in understanding whether international human capital is an effective solution to mitigate the declining young educated populations in peripheral areas (Rowe et al. 2013; Faggian et al. 2016; Tang et al. 2014, 2016), and the extent to which growing up in a peripheral area is an important predictor of return and entry into the labour force following completion of their studies (Rérat 2014). Increasing attention has been dedicated to the factors that attract and retain young educated people in regional areas (Mellander et al. 2011) and the skills profiles of these individuals (Abel et al. 2014; Rowe et al. 2015).

Despite a growing scholarship on youth and graduate migration, a number of areas remain under-researched. The aim of this special issue is to address some of them. In particular, the need to draw on longitudinal data sets such that we can begin to examine longer windows of time to better capture how the spatial mobility of young people from school through university to the labour market intersects with their educational and occupational pathways and impacts on places where they study and work. Through understanding these trajectories, we will have a greater capacity to guide regional development policy on the attraction and retention of human capital and develop more appropriate policy strategies to address skill shortages, particularly in rural areas, and enhancing individual employment outcomes.

\section{Special issue papers}

With an increasing availability of data sets to capture youth and graduation migration, the papers in this special issue draw on a select set of international case studies that examine youth and graduate migration from a cross-sectional and longitudinal perspective, adopting micro- and macromigration approaches (Stillwell and Congdon 1991). The microperspective places the youth, or graduate, as the object of study, while the macroapproach focuses on local labour markets to unveil the characteristics of the locations in which the young people and graduates study and work.

The first article by Perales draws on panel data from the UK and Australia to investigate the relationship between internal migration and job satisfaction. The paper shows that long-distance migration (defined as moves that are greater than $50 \mathrm{~km}$ ) and moves motivated principally by work are positively associated with perceived levels of job satisfaction. This association appears to be especially significant for university graduates.

Five papers examine the determinants of location decisions. The first by Crescenzi and Holman adopts a mixed methods approach on data for Sardinia, Italy, to identify the reasons why graduates (defined as individuals who moved away from their home region to study at university) return to an economically lagging region. Results reveal 
that income does not fully explain this migratory behaviour; rather, family, social networks and quality of life are shown to be important considerations.

The second paper by Winters examines the way in which migration decisions are impacted by earnings in their college major by drawing on microdata from the American Community Survey. Results reveal that where the major-specific earnings are higher than other States for an individuals' state of birth, the probability of migration is reduced. Winter also points to the importance of family and social networks in the decision to migrate.

The third paper by Liu and colleagues draws on microdata for China to examine the migration decisions of graduates from school to university and work. Their results show that regional differences in wages are the main predictors that explain migration decisions. They also suggest that policies which target increasing labour market returns in lagging regions in terms of wages are likely to be more effective at stemming the loss of human capital compared to education investment in these locales.

In a fourth study, Dotzel examines student migration in the USA and examines the role that natural amenities play in student migration decisions to undertake higher education using institution-level data from the National Center for Education Statistics' Integrated Postsecondary Education Data System. Results highlight the importance of natural amenities in the students' decision to migrate along with institutional and regional characteristics.

The fifth paper by Bjerke and Mellander draws on microdata for Sweden to examine short-term (5-year postgraduation) and long-term (10-year postgraduation) location decisions of university graduates. Looking specifically at urban-rural differentials, their results reveal that family is one of the strongest drivers concerning where graduates locate than any other individual factor. They also reveal that this finding is consistent looking at migration decisions across the urban hierarchy.

The paper by Kazakis and Faggian explores the sequential migration decisions of graduates and its connection to their labour market outcomes in the USA accounting also for the problem of migrant self-selection. Their study draws on individual survey data from the Scientists and Engineers Statistical Data System by the National Science Foundation (NSF) to model the combined set of decisions that are to migrate for study and to migrate for employment. Results reveal that repeat migrants tend to be associated with salary premia, while late migrants experience salary losses.

Di Cintio and Grassi focus on the mobility of two cohorts of Italian doctoral graduates using survey data collected by the Italian National Institute of Statistics. Findings show that international mobility is associated with higher wage premiums. Drawing on their findings, the authors suggest that policy targeted at the retention of human capital in a country through incentive schemes needs to account for individual gains associated with the migration allied with increased research funding and prospects.

Venhorst places a focus on the way in which the skill structure of metropolitan areas determines their ability to attract Dutch graduates. Results reveal that labour markets with larger shares of higher and scientific-level employment are related to stronger inflows of recent graduates, indicating a potential positive "production spillover" from this influx. Additionally, inflows of recent graduates are also associated with larger shares of low and medium skill jobs in their residential settlement areas-indicating the existence of a positive 'consumption spillover' effect. 
The final paper by Rowe and colleagues examines the role of youth and graduate pathways in Australia from an urban-rural perspective. Drawing on data from the Longitudinal Survey of Australia Youth, Rowe and colleagues place a particular emphasis in revealing the way migration decisions influence labour market outcomes over a tenyear period. Results show that individuals who decide to remain in non-metropolitan locations were aligned with pathways leading to lower wage returns, while those who migrate to metropolitan areas after school enhance their human capital and earning capacity after three years post-migration. They also indicate that unobserved attributes, such as greater aspirations and motivation were a major feature explaining higher wage returns following migration.

This special issue draws together a set of papers that highlight the importance of youth and graduate migration in the context of both individual career pathways and regional labour markets, along with providing an overview of the various data sets available to study this phenomenon across a range of international contexts, including Australia, China, Italy, the Netherlands, UK and the USA. Through the special issue, we hope that the importance in the collection of spatially detailed longitudinal records of youth and graduate mobility, interfaced with comprehensive data on labour market characteristics, to contribute to developing effective policy will become evident. Furthermore, the papers contained in this special issue offer a new consolidated resource for researchers and policy analysts interested in youth and graduate migration, presenting a variety of policy issues, available data sets and applied methods across a set of international case study contexts.

In summary, the aim of the special issue is to offer a point of reference by showcasing the latest international research on youth and graduate migration. Finally, we would like thank each of the contributing authors, the referees and the editorial team at the Annals of Regional Science.

\section{References}

Abel JR, Gabe TM, Stolarick K (2014) Skills across the urban-rural hierarchy. Growth Change 45(4):499517

Artz G (2003) Rural area brain drain: Is it a reality? Choices 4:11-15

Costa DL, Kahn ME (2000) Power couples: changes in the locational choice of the college educated, 1940-1990. Q J Econ 115(4):1287-1315

Corcoran J, Faggian A (eds) (2017) Graduate migration and regional development: an international perspective. Edward Elgar Publishing, Cheltenham

Corcoran J, Faggian A, McCann P (2010) Human capital in remote and rural Australia: the role of graduate migration. Growth Change 41:192-220

Faggian A, McCann P (2009) Universities, agglomerations and graduate human capital mobility. Tijdschrift voor economische en sociale geografie 100(2):210-223

Faggian A, Corcoran J, Rowe F (2016) Evaluating the effects of Australian policy changes on human capital: the role of a graduate visa scheme. Environ Plann C Gov Policy 34(1):151-170

Global Migration Group (2014) Migration and youth: challenges and opportunities. http://unesdoc.unesco. org/images/0022/002277/227720e.pdf. Accessed 28 May 2017

Gibson J, McKenzie D (2012) The economic consequences of 'brain drain' of the best and brightest: microeconomic evidence from five countries. Econ J 122(560):339-375

Mellander C, Florida R, Stolarick K (2011) Here to stay-the effects of community satisfaction on the decision to stay. Spat Econ Anal 6(1):5-24 
Rérat P (2014) Highly qualified rural youth: Why do young graduates return to their home region? Child Geogr 12(1):70-86

Ritsilä J, Ovaskainen M (2001) Migration and regional centralization of human capital. Appl Econ 33(3):317-325

Rogers AR, Raquillet R, Castro L (1978) Model migration schedules and their applications. Environ Plann A 10:475-502

Rowe F, Corcoran J, Faggian A (2013) Mobility patterns of overseas human capital in Australia: the role of a 'new' graduate visa scheme and rural development policy. Austr Geogr 44(2):177-195

Rowe F, Tang AZR, Corcoran J (2015) Transfer of human capital flows to non-metropolitan economies: University graduates, skills and knowledge in Australia. In: Working Paper 01/2015. Brisbane: Queensland Centre for Population Research

Stockdale A (2006) Migration: pre-requisite for rural economic regeneration? J Rural Stud 22(3):354-366

Stillwell J, Congdon P (1991) Migration models: macro and micro approaches. Belhaven Press, London

Tang AZR, Rowe F, Corcoran J, Sigler T (2014) Where are the overseas graduates staying on? Overseas graduate migration and rural attachment in Australia. Appl Geogr 53:66-76

Tang A Z R, Rowe F, Corcoran J, Sigler T (2016) Spatial mobility patterns of overseas graduates in Australia. In: Demography for planning and policy: Australian case studies, pp 175-195. Springer International Publishing

United Nations (2016) Youth and migration. Youth Issue Briefs 2016, UN Department of Economic and Social Affairs. Available at: http://www.un.org/esa/socdev/documents/youth/fact-sheets/youthmigration.pdf. Accessed 28 May 2017

Venhorst V, Van Dijk J, Van Wissen LEO (2010) Do the best graduates leave the peripheral areas of the Netherlands? Tijdschrift voor economische en sociale geografie 101(5):521-537 